\title{
The Financial Behavior of Investment Decision Making Between Real and Financial Assets Sectors
}

\author{
Yusriadi HALA ${ }^{1}$, Muhammad Wahyuddin ABDULLAH ${ }^{2}$, Wuryan ANDAYANI ${ }^{3}$, \\ Gunawan Bata ILYAS ${ }^{4}$, Muhammad AKOB ${ }^{5}$
}

Received: September 10, 2020 Revised: November 08, 2020 Accepted: November 16, 2020

\begin{abstract}
This research was conducted to achieve several objectives and focus research was based on financial behavior theory and prospect theory as grounded theory e.g., investigate the financial decision-making behavior between financial and real assets investment, and confirm the relationship existing between herding behavior and overconfidence factors to the level of loss and regret aversion, and financial literacy into real assets investment decisions. The study used 220 real estate auction respondents as investor samples at the State Assets and Auction Service Office Makassar, South Sulawesi, Indonesia. Data was collected through the use of a questionnaire consisting of 23 questions to measure the variables. Moreover, the research data passed through several feasibility tests like the inner and outer modeling by Partial Least Square - Structural equation model (PLS-SEM) while the hypotheses formulated were also tested to determine the magnitude of the variable relationship. Through the use of the direct and intervening test, loss and regret aversion variables have a positive and significant effect while financial literacy variables have no significant effect. There is a slight difference in the decision-making process for real assets and financial assets investors. Investment decision making behavior in the financial assets sector requires less complicated decisions compared to the decisions related to real assets investments.
\end{abstract}

Keywords: Finance Behavior Theory, Prospect Theory, Investment Decision Making, Real Assets

JEL Classification Code: G11, G32, G40, G41

\section{Introduction}

Investment is defined as investment activity or activity, while an investor is a person or legal entity with the money to invest or invest. Investment is the placement of a fund that we have today, hoping that it will bring benefits in the

${ }^{1}$ First Author and Corresponding Author. Assistant Professor, Department of Accounting, STIEM Bongaya, Makassar, Indonesia [Postal Address: Jalan. Let. Jend. Mappaoddang No.28, Bongaya, Kec. Tamalate, Kota Makassar, Sulawesi Selatan 90131, Indonesia] Email: halayusriadi@gmail.com

${ }^{2}$ Associate Professor, Department of Accounting, Faculty of Economic and Business, Universitas Islam Negeri (UIN) Alauddin, Makassar, Indonesia

${ }^{3}$ Associate Professor. Faculty of Economics \& Business, Department of Accounting, Universitas Brawijaya Malang, East Java, Indonesia ${ }^{4}$ Associate Professor, Department of Management, STIE AMKOP, Makassar, Indonesia

${ }^{5}$ Associate Professor, Department of Management, STIEM Bongaya, Makassar, Indonesia

(c) Copyright: The Author(s)

This is an Open Access article distributed under the terms of the Creative Commons Attribution Non-Commercial License (https://creativecommons.org/licenses/by-nc/4.0/) which permits unrestricted non-commercial use, distribution, and reproduction in any medium, provided the original work is properly cited. future (Nguyen et al., 2020). When we invest, at least we have planned to have a better life in the future. Investments are classified into two categories: investment in financial assets and investment in real assets. The capital market has a critical role in investment because transactions occur between owners of capital and companies that issue investment products (Sarsour \& Sabri, 2020). Investment products, such as stocks, can provide substantial returns but are always directly proportional to considerable risks. Investors should first know some of the information needed before investing, such as information about stock prices. This is important because when investors do not see any information about investments, especially stocks, it could be an investor's loss. Moreover, stocks do have a significant risk, so a lot of accurate information is required before making investments. (Mittal, 2010). In a recent study, Khanam (2017) also reported the influence of demographic factors such as age, level of education, occupation, trading experience, and level of investor income. In contrast, behavioral finance researchers argue that investors tend to behave irrationally in the investment decision-making process due to the influence of several psychological factors (Kiyilar \& Acar, 2013; López-Gutiérrez et al., 2015; Chen et al., 1995). 
Moreover, through the reflection of the prospect theory perspective on finance behavior, it has been concluded by some opinions and definitions that behavioral finance is a subsystem of psychology in the Economics field (Pompian \& Wood, 2006; Kiyilar \& Acar, 2013).

Another irrational consideration of investors in making investment decisions is herding which is defined as a followup to the behavior of others after comparing the beliefs and information they have on a particular investment (Hirshleifer \& Hong Teoh, 2003). It is mostly caused by the prediction errors of investors to invest in a business based on the decisions of others (Scharfstein \& Stein, 1990). In addition, a previous study by Nofsinger and Sias (1999) explained that herding occurs due to the movement of a group of investors in the same direction and at the same period. This means herding behavior is specifically a tendency to follow what other people are doing based on their knowledge, understanding, and experience to avoid bad judgement from the failure of the decisions made and also to ensure there is less burden of loss which has the ability of having a significant psychological impact on the investors (Deng et al., 2018).

Apart from herding, there are other cognitive factors and psychological aspects affecting investment decision making and an example is overconfidence. It is defined as a tendency for people to overestimate their knowledge, abilities, and information (Bhandari \& Deaves, 2006). Moreover, a high self-confidence in an investor's ability and knowledge usually leads to a higher belief in the ability to predict, analyze, and make accurate decisions compared to others (Shefrin, 2007). For example, the studies conducted by Gervais and Odean, (2001) and Alrabadi et al. (2011) showed that an increase in investor's experience affects the level of overconfidence. Furthermore, increasingly overconfident investors are usually brave in making investment decisions through the use of the knowledge and information held and tend not to conform to herding. However, both herding and overconfidence factors are driven by emotional factors and they are an essential aspect of every individual with the ability to influence the decision-making process, either positively or negatively (Ackert et al., 2003).

From the financial decision-making perspective, emotional factors are classified into two aspects, loss aversion, and regret aversion. Loss aversion is one of many factors influencing investment decisions through the determination of the level of courage required by an individual to take a risk (Kahneman, 1979) and it was introduced by Thaler (1980) in a risky decision in prospect theory. It involves a situation where a person holds shares longer when experiencing loss and sell when there is a profit. This was reiterated by Kahneman, Knetsch, and Thaler (1990) and Haigh and List (2005) that the level of sensitivity of a person to losses is more than doubled compared to the profits obtained even though the benefits achieved also increased. Loss aversion significantly affects investment decisions especially in determining if an investor has a riskseeking or risk-averse tendencies. Moreover, in relation to herding, investors usually in a loss aversion position tend to act alone in making investment decisions.

On the contrary, regret aversion is defined as the fear of taking actions to avoid making the same mistakes while making investment decisions and it is majorly associated with the avoidance of losses. Therefore, the existence of fear influences the decision-making process in such a way that if an investor is classified as risk-averse, after facing losses, is likely to be emotionally discouraged to invest. Moreover, in relation to herding, investors suffering continuous losses are usually less confident and this makes them follow the decisions of others (Pompian \& Wood, 2006). Psychological factors in investment decision making can be balanced with good and optimal financial literacy abilities (Kim, 2004; Akims \& Jagongo, 2017). Financial literacy is defined as the ability and knowledge to manage income and expenditure through the use of monetary exchange and management methods (Sarigül, 2014). It is often associated with an understanding of daily activities such as insurance, credit, savings, loans, investments, and fund management to increase wealth. Moreover, financial management is essential for all professions, especially investment actors, and excellent financial literacy support has been discovered to have the ability to improve investors' overconfidence and minimize herding.

Therefore, this study was conducted to first investigate and reconfirm the psychological role of real asset investors, especially those focusing on auctions such as land, cars, house buildings, warehouses or factories, etc. for resale, in Indonesia. Second, adopt and reinvestigate the results obtained from a study conducted by Khanam (2017) to determine the influence of several intervening variables such as loss aversion, regret aversion, financial literacy, herding, and overconfidence on investment decisions. However, Khanam (2017) and several similar studies have made use of respondents in financial asset investments while this study was focused on real asset investors.

This research was conducted to achieve several objectives and they include 1) determining if the same financial decision-making behavior in financial asset investments also apply to the investments in the real assets. Some factors are considered crucial for investments in the real assets compared to financial asset sector and these include the need for large budget to win an auction, completeness or formal legal assets, as well as the condition of the assets being auctioned, and 2) to empirically test and confirm the relationship between herding and overconfidence factors to the level of loss aversion, regret aversion, financial literacy in making real asset investment decisions. 


\section{Literature Review}

\subsection{The Finance Behavioral and Prospect Theory}

Initially, individuals who make investments not only use estimates of the prospects for investment instruments, but psychological factors also determine the investment decisions. The existence of these psychological factors affect investment decisions and the results to be achieved (Xiao, 2008). Investment analysis using psychology and financial science is known as economic behavior or financial behavior. Shefrin (2007) defines behavioral finance as a study about how psychological phenomena affects financial behavior. The stock players' behavior is where Shefrin states the practitioners' level of action. Marilena and Alice (2012) define financial behavior as how humans behave in a financial setting. Before the emergence of the behavioral finance theory, there was a traditional theory or fundamental economics which links finance to economic theory with the assumption that all participants have the same information in the market. Moreover, most of the internal factors causing irrational actions are psychological (Sahi et al., 2013) and also serve as the basis for desires, motivations, and sources of error due to the possibilities of excessive overconfidence, wrong perception, illiteracy, and inability to control emotions, especially negative ones (Michailova \& Schmidt, 2016; Meier \& De Mello, 2019). Therefore, the gap between the fundamental theory and actual market conditions led to the introduction of the behavioral finance theory to address the influence of psychology on financial behavior (Shefrin, 2007; Bhandari \& Deaves, 2006). However, the Prospect Theory was initiated by Kahneman (1979) as a part of behavioral finance to explain the behavior of investors.

Prospect theory was formulated to criticize the utility of approaches deemed less able to explain individual behavior in making decisions. Kahneman and Tversky (2013) stated the expected utility theory is dominated by the analysis of risk-making decisions as a normative model for rational choice and widely applied to describe economic behavior. Furthermore, Kahneman (1979) focused on the cognitive and heuristic biases causing unexpected irrational actions of investors (Kliger \& Tsur, 2011). Therefore, the prospect theory is established on the principle that there is a tendency for someone to act irrationally due to the reluctance to risk gains compared to losses (Cianci, 2008). The theory is depicted by Kahneman and Tversky (2013) in a hypothetical value function to explain the role of values based on the deviation from the reference point of gain and loss. However, it has been discovered that the loss position has a more significant influence in terms of psychology than gain (Braga \& Fávero, 2017). This was associated with the high sense of low self-esteem and regret observed with the loss compared to the pleasure obtained from receiving again.

\subsection{Investment Decision-Making}

This is an investor's action to invest funds in several investment options, both in the financial and real assets (Hilton, 2001; Cheng, 2014). Investing in any business requires the consideration of several factors, both external and internal. External factors include the company's financial statements, inflation, prevailing interest rates, or several supporting letters for the existence of assets (Sevdalis \& Harvey, 2007; Oehler et al., 2018). Internal factors are mostly psychological and involve cognitive, affective and psychomotor levels (Statman, 2017). The cognitive aspect is related to intellectual ability and thinking both in terms of knowledge, understanding, application, analysis, evaluation, and others while affective includes ethical behavior, feelings, attitudes, emotions, and others. The emergence of psychological biases in behavioral finance tends to shift rational to irrational actions while making investment decisions (Peters, 2003). According to Mittal (2010), a biased and sometimes irrational behavior of an investor is greatly influenced by emotions and mood during the investment decision-making process. This is in accordance with the submission of Kahneman (1979), and Kahneman and Tversky (2013) that when humans are in a state of uncertainty, there is a shift from fundamental economic theory in making investment decisions. It was also reinforced by the opinion of Brunsson (2014) that uncertainty shows the decision-makers' lack of confidence in the information available and risks due to the difficulty experienced in decision making. This uncertainty was also found to be caused by the possibility of cognitive structure, unclear judgment, and change of estimation (Brunsson, 2014). Furthermore, internal factors also dominate in influencing the courage exhibited by an investor, either as a risk-seeking or risk averter, in making investment decisions (Kliger \& Tsur, 2011; Fong, 2013; He \& Choi, 2020; Nguyen, 2020).

\subsection{Herding Behavior}

Herding occurs due to the movement of a group of investors in the same direction and at the same period (Nofsinger \& Sias, 1999). It is a behavior involving the tendency to mimic the actions of others rather than follow the information and knowledge obtained personally (Hirshleifer \& Teoh, 2003; Rompotis, 2018). According to Land and Rose (2011), it is defined as an individual's propensity to follow others in making the same investment due to the lack of public information. This was also confirmed by Jurkatis, Kremer, and Nautz, (2012) that the concept emerged due to the lack of transparency in the market place leading to uncertain public information sources and unclear corporate signals. Baddeley et al. (2012), Andersson et al. (2014) and Alda and Ferruz 
(2016) also reported the occurrence of herding due to the restriction of public data and information to certain groups in decision making. However, (Venezia et al., 2011) argued there are rational herding actions as observed from some pieces of literature and they include information-based, reputationbased, and compensation-based (Venezia et al., 2011).

Information-based herding involves using the data gathered from observing other investors that have earlier invested in stock to correct error bias (Venezia et al., 2011; Banerjee, 1992; Bikhchandani et al., 1992). Reputationbased herding involves a situation where two managers and employer investments are not sure of the skills possessed by the two managers (Venezia et al., 2011; Froot et al., 1992). Compensation-based herding involves the initial compensation of an investment manager associated with several market benchmarks and the discovery of activities to be mimicked or copied by other investors (Venezia et al., 2011; Maug \& Naik, 1996). The major element of rational herding is the reception of the same signal by investors towards making the same decision in order to maximize profits while irrational herding involves decisions made in a panic and emotional condition due to other investors' shares or asset transactions and which causes instability if any unexpected error occurs in both the financial and asset markets. For the purpose of this research, the scope was limited to herding behavior in making investment decisions on real assets (Lee \& Lee, 2015).

\subsection{Overconfidence}

Overconfidence is defined to be an excessive feeling of confidence with the ability to make investors have the courage to see risk as being insignificant when making decisions (Deaves et al., 2019; Morales-Camargo et al., 2015). Conversely, those with less confidence tend towards being cautious in making risky investment decisions because the risk is considered a big problem (Stotz \& von Nitzsch, 2005). Moreover, overconfidence makes investors overestimate their knowledge and underrate predictions due to the fact they believe more in their abilities than they should (Nofsinger, 2017). In another study, the concept is defined as the tendency of an individual to overvalue its knowledge, abilities, and information (Bhandari \& Deaves, 2006). This is associated with several factors such as gender, age, experience, past performance, advice, and management qualification. It has also been discovered that uncertainties can lead to overconfidence through the process of making overestimated decisions (Fischhoff, 2003; Kartini \& Setiawan, 2017; Stotz \& von Nitzsch, 2005). Shefrin (2007) reported overconfidence bias is divided into two - based on ability and knowledge. Furthermore, there is ability to predict, analyze, and make accurate decisions when an individual has a high level of confidence compared to others, however, it has also been reported that overrated selfconfidence is only an illusion of experience and skill due to limited or lack of expertise in interpreting information (Baker \& Nofsinger, 2002; Lovric et al., 2010). This, therefore, means it is possible for investors to become overconfident through advice obtained from those with more experience in the field, and the level of experience determines the rate at which an individual is overconfident (Gervais \& Odean, 2001; Alrabadi et al., 2011).

\subsection{Emotional Bias}

Emotions are an essential aspect of an individual with an influence on the outcome of a decision (Ackert et al., 2003). According to Hirshleifer (2001), emotions play an important role in ambiguous conditions, especially when individuals are afraid to take risks (Riff \& Yagil, 2016). This shows the significance of psychology - both affective which involves emotions and cognitive which involve the intellect, knowledge, and sensitivity of an individual in the process of making any business decision. This was affirmed by the Decision Affect Theory that emotions from some selected actions have effects on decisions (Mellers et al., 1997; Mellers et al., 1999; Guzak, 2015). This is mostly observed in how an individual learns, remembers, thinks, takes risks, receives, or understands very complex social information associated with decision-making (Bower, 1981; Bless et al., 1996). There are several factors of emotions affecting financial decisions and they include loss aversion, regret aversion, or the status quo. However, this study was limited to only two of these, and they are loss and regret aversions.

\subsection{Loss Aversion}

Loss aversion is a process of holding more shares of stock in the event of a loss to sell when there is profit (Kahneman, 1979). It is also defined as the tendency of an individual to be more sensitive when there is loss compared to when there is a gain (Thaler et al., 1997). People with loss aversion are more cautious in making investments during the period when there is no profit in comparison with the times there is enough gain (Haigh \& List, 2005). It also involves holding the stock when the market experiences losses with the expectation the price is going to increase in the future. These definitions and explanations show individuals possessing loss aversion are less daring and tend to have herding behavior while making investment decisions and vice versa (Dräger et al., 2014). Based on the explanations, the following hypotheses were formulated:

H1: Loss aversion affects investment decision

H2: Loss aversion through herding as an intervening variable influences investment decision 


\subsection{Regret Aversion}

This is defined as the fear of taking actions to avoid making the same mistakes while making investment decisions (Pompian \& Wood, 2006; Chorus, 2014; Corzo et al., 2014). This concept emerged due to the desire of investors to avoid the expected regrets which comes from making wrong investment decisions. It also creates concerns for both individual and group investors over price fluctuations which may cause losses in real estate and current financial assets in the market. Moreover, the main idea behind this concept involves holding back poorly performing stocks and selling the shares when the market shows a profit. According to Pompian and Wood (2006), regret aversion has the ability to make investors become too conservative and under-risk against the market due to the continuous losses being experienced and this may consequently lead to herding. This phenomenon serves as the foundation for the regret theory developed by Loomes and Sugden (1982) and Bell (1982) which is considered an irrational theory of choice in uncertainty conditions. However, for the purpose of this study, the regret aversion was explained based on prospect theory.

H3: Regret aversion influences investment decisions.

H4: Regret aversion through herding as an intervening variable influences investment- decisions.

\subsection{Financial Literacy}

Financial science is dynamic and firmly attached to everyday practices, therefore, absolute financial knowledge is optimally required, especially when an individual is offered several commercial products. Making the right decision requires adequate knowledge, information, and understanding of finances and other things attached to it. Cole and Fernando (2008) defined financial literacy as the ability to read, analyze, manage, and write the finances affecting the life of a person. According to Abreu and Mendes (2010), only a few know the impact of this concept on investment diversification and its ability to explain problems with investor behavior. A study conducted (e.g., Aryeetey, 2004; Kim, 2004; Akims \& Jagongo, 2017; Ahunov \& van Hove, 2019; Gil, 2015) found the effect of financial literacy on financial decision-making. These, however, led to the formulation of the following hypotheses:

H5: Financial literacy affects investment decisions.

H6: Financial literacy through herding as an intervening variable influences investment- decisions.

H7: Financial literacy through overconfidence as an intervening variable influences investment-decisions.

H8: Financial literacy through overconfidence and herding as an intervening variable influences investment-decisions.
Table 1: Measurement of Variable

\begin{tabular}{|c|c|c|}
\hline $\begin{array}{l}\text { Auction } \\
\text { Experience } \\
\text { (times) }\end{array}$ & $\mathbf{N}$ & $\%$ \\
\hline $1-2$ times & 76 & 34,5 \\
\hline $3-5$ times & 95 & 43,1 \\
\hline $5-10$ times & 49 & 22,2 \\
\hline Total & 220 & 100 \\
\hline Variabel & \multicolumn{2}{|c|}{ Indicator / Item } \\
\hline $\begin{array}{l}\text { Loss Aversion } \\
\text { (X1) }\end{array}$ & \multicolumn{2}{|c|}{$\begin{array}{l}\text { - } \mathrm{X} 1.1 \text { efforts to avoid losses } \\
\text { - } \mathrm{X} 1.2 \text { invest in the same type of assets } \\
\text { from time to time } \\
\text { - } \mathrm{X} 1.3 \text { Sell assets when the price is } \\
\text { loss and will be held when the price } \\
\text { is high }\end{array}$} \\
\hline $\begin{array}{l}\text { Regret Aversion } \\
(\mathrm{X} 2)\end{array}$ & \multicolumn{2}{|c|}{$\begin{array}{l}\text { X2.1 perception of fear of loss } \\
\text { - X2.2 perception of loss so try to avoid } \\
\text { loss }\end{array}$} \\
\hline $\begin{array}{l}\text { Financial } \\
\text { Literacy (X3) }\end{array}$ & \multicolumn{2}{|c|}{$\begin{array}{l}\text { - X3.1 basic personal finance } \\
\text { - X3.2 financial management } \\
\text { - } \text { X3.3 credit and debt management } \\
\text { - } \text { X3.4 saving and investment } \\
\text { - } \text { X3.5 risk management }\end{array}$} \\
\hline $\begin{array}{l}\text { Overconfidence } \\
\text { Bias (X4) }\end{array}$ & \multicolumn{2}{|c|}{$\begin{array}{l}\text { - X4.1 Confident in the ability to } \\
\text { analyze accurately } \\
\text { - X4.2 very confident of the knowledge } \\
\text { possessed }\end{array}$} \\
\hline Herding (X5) & \multicolumn{2}{|c|}{$\begin{array}{l}\text { - X5.1 The price determination follows } \\
\text { other investors } \\
\text { - X5.2 The investment was made } \\
\text { because it was intended from the } \\
\text { start } \\
\text { X5.3 React quickly if you receive } \\
\text { information from previous investors } \\
\text { - X5.4 Investments are often made } \\
\text { because of advice from other parties } \\
\text { - X5.5 Investments are made if } \\
\text { the compensation provides a } \\
\text { considerable profit }\end{array}$} \\
\hline $\begin{array}{l}\text { Investment } \\
\text { Decision }(Y)\end{array}$ & \multicolumn{2}{|c|}{$\begin{array}{l}\text { - Y1 Knowledge of auctions } \\
\text { - Y2 Financial management } \\
\text { - Y3 Investment criteria } \\
\text { - Y4 Price fluctuations } \\
\text { - Y5 Financial Budget } \\
\text { - Y6 Feelings felt by investors in } \\
\text { making investment decisions }\end{array}$} \\
\hline
\end{tabular}




\section{Research Methods and Materials}

The samples used include 105 real estate auction investors at the State Assets and Auction Service Office (KPKNL) South Sulawesi, Indonesia that has participated in a real asset auction 1-10 times and selected using purposive sampling. Data was collected using a questionnaire consisting of 23 questions as shown in Table 2 and analyzed using quantitative analysis. Likert scale ranging from 1 for strongly disagree to 5 for strongly agree was used. The three independent variables used include Loss Aversion (X1) consisting of three constructs (X1.1 - X1.3), Regret aversion (X2) consisting of two constructs (X2.1 - X2.2), and Financial literacy (X3) consisting of five constructs (X3.1 - X3.5).

Furthermore, two intervening variables were used including Overconfidence (X4) which is composed of two construct items (X4.1 - X4.2) and Herding (X5) consisting of five constructs (X5.1 - X5.5). The dependent variable was the Investment Decision (Y) with six constructs (Y1 - Y6). In addition, the model developed included the moderation and intervening effects of financial literacy and overconfidence variables as shown in Figure 1. The research data was tested for reliability and validity (Hair et al., 2017), (Chin, 1998), through the use of Cronbach alpha, composite reliability, F-test, R-square, with AVE $>0.60$ and outer-loading > 0.50 through the application of non-parametric statistical applications Smart-PLS and reviewed using the Consistent PLS-Algorithm section with the criteria being the weighting scheme path and maximum literation of 300 . Moreover, the hypotheses were tested to determine the magnitude of the coefficient of influence and relationship in the consistentbootstrapping sub-section with 105 sub-sample and confidence interval method using the Bias-Corrected and accelerated (BCa) Bootstrap two-tailed at a sig. level of 0.05 .

\section{Results and Discussion}

\subsection{Results}

The inner model was used to measure the interior or structural model connecting the latent variables through the use of R-Squared or $\mathrm{R}^{2}$. Moreover, the results obtained from the outer and inner statistical tests are presented in Table 2 and supported by the model fit in Fig 1.

Table 2 shows all the latent variables have values of Cronbach's alpha greater than 0.6 and this means they are all reliable without any reflective indicators. This was also supported by the results from composite reliability which were also greater than 0.7 while the validity test showed a greater convergent. Besides, the model also showed the value of the outer model by measuring the efficacy through the use of both convergent and discriminant validity. The convergent validity showed each latent variable has AVE value greater than 0.5 and this means they have the ability to explain more than half the variants for all indicators on the average. This was also supported by discriminant validity where the cross-loading of each latent variable showed a value $>0.7$ to indicate they are not highly correlated. This, therefore, means the outer model of this study is reliable and valid.

The inner model measured with $\mathrm{R}$ Square includes endogenous latent variables including herding, investment, and overconfidence. Herding has a R2 value of 0.893 as a model in the current category, Investment has 0.784 in the active group, while Overconfidence has 0.601 and was placed in the moderate category.

Table 2: Outer Model and Inner Model

\begin{tabular}{|c|c|c|c|c|c|c|}
\hline \multirow{3}{*}{ Model } & \multicolumn{4}{|c|}{ Outer model } & \multirow{2}{*}{\multicolumn{2}{|c|}{ Inner model }} \\
\hline & \multicolumn{2}{|c|}{ Reliability } & \multicolumn{2}{|c|}{ Validity } & & \\
\hline & $\begin{array}{c}\text { Cronbach's } \\
\text { Alpha }\end{array}$ & $\begin{array}{c}\text { Composite } \\
\text { reliability }\end{array}$ & AVE & $\begin{array}{l}\text { Cross } \\
\text { Loading }\end{array}$ & R Square & $\begin{array}{c}\text { R Squared } \\
\text { Adjusted }\end{array}$ \\
\hline Financial Literacy & 0.852 & 0.895 & 0.632 & 0.795 & & \\
\hline Herding & 0.891 & 0.920 & 0.697 & 0.835 & 0.893 & 0.889 \\
\hline Investment Decisions & 0.845 & 0.871 & 0.540 & 0.735 & 0.784 & 0.767 \\
\hline Loss Aversion & 0.645 & 0.807 & 0.584 & 0.764 & & \\
\hline Mod_FinLet & 1.000 & 1.000 & 1.000 & 1.000 & & \\
\hline Mod_Overconfident & 1.000 & 1.000 & 1.000 & 1.000 & & \\
\hline Over Confidence & 0.758 & 0.891 & 0.804 & 0.897 & 0.601 & 0.597 \\
\hline Regret Aversion & 0.641 & 0.847 & 0.735 & 0.857 & & \\
\hline
\end{tabular}




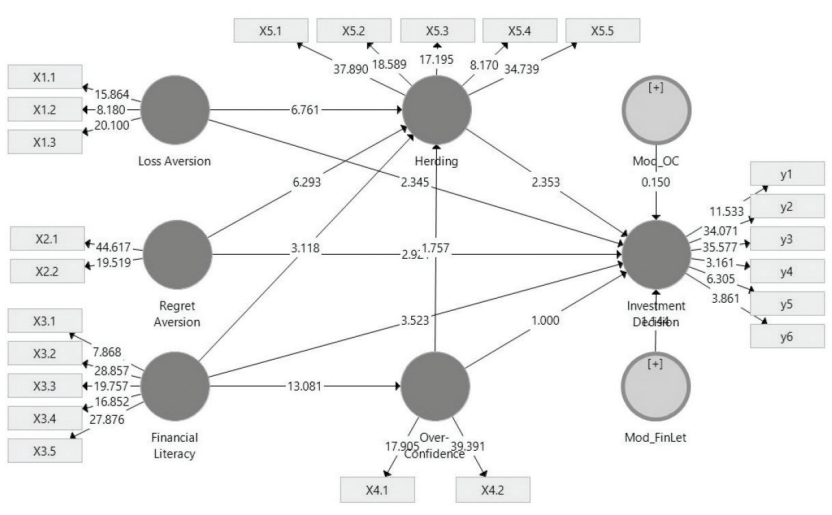

Figure 1: Model Analysis of Smart-PLS
The path coefficient was used to determine the latent variable predictor of the structural level with the criteria being that if $\mathrm{f}^{2}$ is 0.02 it is weak, 0.15 is enough, while 0.35 is strong. The results in Table 3 show the robust predictor was observed with regret aversion to herding and financial literacy to overconfidence, sufficiency was found with loss aversion to herding path while the other lines showed weak predictors. After the conduct of the outer and inner model as well as the path coefficient, the hypotheses were tested using PLS-SEM at a significance level of $10 \%$ and the results are presented in Table 3.

Table 4 shows the loss aversion and investment decision have a significant positive effect as observed with the P-value of 0.033 which is below the $10 \%$ significance level used in this study. This means more loss aversion would lead to less courage in making investment decisions.

Table 3: Path coefficient (F2)

\begin{tabular}{|l|c|c|c|}
\hline \multirow{2}{*}{ Variables } & \multicolumn{3}{|c|}{ Matrix F Square } \\
\cline { 2 - 4 } & Herding & $\begin{array}{c}\text { Investment } \\
\text { decisions }\end{array}$ & Overconfidence \\
\hline Financial Literacy & 0.086 & 0.143 & 1.504 \\
\hline Herding & & 0.067 & \\
\hline Investment Decisions & & & 0.076 \\
\hline Loss aversion & 0.290 & 0.020 & \\
\hline Mod_Financial literacy & & 0.000 & \\
\hline Mod_OverConfidence & & 0.010 & \\
\hline Over Confidence & 0.061 & 0.112 & \\
\hline Regret Aversion & 0.373 & & \\
\hline
\end{tabular}

Table 4: Hypothesis Test Results

\begin{tabular}{|c|c|c|c|c|c|}
\hline Path & Mean & $\begin{array}{l}\text { Standard } \\
\text { Deviation }\end{array}$ & T-Stats & P-Value & Info \\
\hline Loss Aversion $\rightarrow$ Investment Decision & -0.185 & 0.083 & 2.141 & 0.033 & Supported \\
\hline $\begin{array}{l}\text { Loss Aversion } \rightarrow \text { Herding Behavior } \rightarrow \text { Investment } \\
\text { Decision }\end{array}$ & -0.185 & 0.083 & 2.141 & 0.033 & Supported \\
\hline Regret Aversion $\rightarrow$ Investment Decision & -0.123 & 0.056 & 2.104 & 0.036 & Supported \\
\hline $\begin{array}{l}\text { Regret Aversion } \rightarrow \text { Herding Behavior } \rightarrow \text { Investment } \\
\text { Decision }\end{array}$ & -0.123 & 0.056 & 2.104 & 0.036 & Supported \\
\hline Financial Literacy $\rightarrow$ Investment Decision & -0.142 & 0.080 & 1.762 & 0.079 & Not Supported \\
\hline $\begin{array}{l}\text { Financial Literacy } \rightarrow \text { Herding Behavior } \rightarrow \text { Investment } \\
\text { Decision }\end{array}$ & -0.118 & 0.066 & 1.778 & 0.076 & Not Supported \\
\hline $\begin{array}{l}\text { Financial Literacy } \rightarrow \text { Overconfidence } \rightarrow \text { Investment } \\
\text { Decisions }\end{array}$ & -0.064 & 0.064 & 0.950 & 0.343 & Not Supported \\
\hline $\begin{array}{l}\text { Financial Literacy } \rightarrow \text { Overconfidence } \rightarrow \text { Herding } \rightarrow \\
\text { Investment Decision }\end{array}$ & 0.039 & 0.032 & 1.151 & 0.250 & Not Supported \\
\hline
\end{tabular}


The same was found with the use of herding as the intervening variable with the result showing a negative effect as observed from a P-Value of 0.033 and a sample mean of -0.185 . Moreover, there was no adverse significant effect of financial literacy on Herding with the P-value of 0.109 which is higher than the $10 \%$ significance level but financial literacy had an adverse effect on investment decisions. The same was also found with the use of herding as an intervening variable. On the contrary, through the intervention of overconfidence and herding, financial literacy was found in a positive direction and with no effect on investment decisions. Furthermore, there was no significant relationship between other variables including overconfidence on investment decisions, financial literacy on overconfidence, financial literacy on herding through overconfidence, and overconfidence on investment decisions through the use of herding as the intervening variable.

\subsection{Discussions}

The findings showed an individual with increasing loss aversion tends to be more afraid to make investment decisions, and is mostly risk-averse. This is in line with the description of Kahneman and Tversky (1979) and Kahneman (1979a) that a person in a losing position would hold the stock longer up to when there is enough profit in the business. Moreover, even though the respondents of this research were real asset investors with experience in auctioning of assets such as houses, cars, factories, warehouses, and others requiring considerable funds, the results showed if assets auctioned are offered at lower prices, investors would make a quick purchase and vice versa. Furthermore, assets obtained through auction would also be resold as fast as possible when the market price rises and considered to be beneficial. Conversely, if the price of the asset owned decreases or when the increase does not correspond with the effort, the asset would be retained and not released for sale. Therefore, the simple logic is to hold assets owned when prices go down and sell when it rises in order to earn significant profits. But when getting a benefit is considered something normal that should be obtained. Furthermore, this study showed real assets investors have a cautious tendency in making investment decisions due to the consideration of several things such as the physical condition and completeness of the documents guaranteeing the security of the assets to avoid having greater loss and regret.

Loss aversion was found to have a negative influence on decision making through the use of herding variables as the mediator to affirm the first hypothesis. However, the path analysis showed a positive impact between loss aversion and herding and this means investors with high loss aversion tend to exhibit herding behavior. Moreover, the reason some real estate investors believe more in the information, advice, knowledge, and actions obtained from others in deciding on an investment is to ensure the blame from the loss is shared and to reduce the feeling of regret. However, the mean sample showed investors with high loss aversion and tendency to herd are not too dominating because they are cautious about the information, advice, and actions not obtained from others. This shows despite the fact they tend to decide based on others' direction, they tend to be more careful during the process. Furthermore, investors with loss aversion sometimes do not herd due to some important factors attached to investment such as the significant funds required, ownership validity, bureaucracy, and whether or not the assets can be resold. After the auction has been won, investors become highly afraid and cautious due to the loss aversion. Besides, the courage level is not only influenced by external factors but also by internal ones especially from the affective side like emotions. This is in agreement with the findings of Ackert et al. (2003) that emotions play an essential part, either negative or positive, in decision-making.

On the contrary, hypothetically, if an investor has a low loss aversion there is a tendency to make investment decisions primarily based on the information and advice obtained from others. This means the less perception of loss aversion leads to a greater tendency to exhibit herding behavior as well as a high level of courage in making investment decisions. Moreover, an investor with a low level of loss aversion usually has a high sense of regret after a loss and, therefore, continuously prefers herding. The respondents showed a position of loss aversion by being extra careful in a situation of loss and this is in agreement with the findings of Haigh \& List, (2005) that real asset auction investors deliberately assume tangible assets with a high level of market prices are to be immediately resold while those deemed unprofitable should be retained until the price rises. These actions both during the auction and resell basically follows the prospect theory of Kahneman (1979). It is important to note that the findings of this study regarding the relationship between loss aversion and herding are not precisely in line with previous studies like Haigh and List (2005). However, the overall effect of herding, as intervening variables, strengthens the negative influence between loss aversion and investment decisions as hypothesized. Aversion retreat is defined as the actions caused by the influence of an individual's emotions. In line with the studies of Ackert et al. (2003) and Pompian (2006.) showing the influence of emotions on individual decisions, positive or negative, the regret aversion was due to the feelings of fear to take actions in order to avoid the same mistakes and this was found to be influenced by previous good or bad experiences, specifically for auctioned goods. These could be through the excessive fear of huge losses, both financially and nonfinancially as well as other things to be considered such as the completeness of the required documents, bureaucracy in the region, and the nature of the assets won. 
The negative impact of financial literacy on investment decisions is contrary to the findings(Cole \& Fernando, 2008; Vitt, 2005; Shefrin, 2007) where a higher level of financial literacy led to the ability to process more information and make personal decisions. It also contradicts other previous studies due to the fact real asset investors used in this study were faced with valuable information which required careful consideration before an investment decision was made. Moreover, the finding showing financial literacy does not influence overconfidence is supported by Gervais and Odean (2001) and Alrabadi et al. (2011).

\section{Conclusion}

There is a slight difference in the decision-making process for real asset and financial asset investors. This is observed in the fact that financial asset investors have a large number of shares offered and the number purchased depends on the funds held while real asset investors have limited assets which are contested by many investors and only won with significant funds. Moreover, there the variation in the bureaucracy and information is such that investments in financial asset sector requires less complicated decisions compared to real asset where there are a lot of administrative problems to be considered based on the asset auctioned as well as other things such as the validity of asset ownership, strategic location, cost of repairs, and uncertain time of resale. Even though excellent financial literacy has the ability to increase the level of overconfidence, it does not influence decision-making instantly due to several other factors to be considered.

\section{References}

Abreu, M., \& Mendes, V. (2010). Financial literacy and portfolio diversification. Quantitative Finance, 10(5), 515-528. https:// doi.org/10.1080/14697680902878105

Ackert, L. F., Church, B. K., \& Deaves, R. (2003). Emotion and financial markets. Federal Reserve Bank of Atlanta Economic Review, 88(2), 33-41.

Ahunov, M., \& van Hove, L. (2019). National culture and financial literacy: international evidence. Applied Economics,52(21), 2261-2279. https://doi.org/10.1080/00036846.2019.1688241

Akims, M. A., \& Jagongo, A. (2017). Financial Literacy and Its Impact on Investment Decisions in Nigeria: A Theoretical Perspective. International Journal of Scientific Research and Innovative Technology, 4(11), 18-24.

Alda, M., \& Ferruz, L. (2016). Pension Fund Herding and the Influence of Management Style. Journal of Behavioral Finance, 17(2), 144-156. https://doi.org/10.1080/15427560.2 016.1133625

Alrabadi, D. W., AL-Gharaibeh, M. A., \& Ziad, M. Z. (2011). What Makes Investors Overconfident? Evidence from Amman
Stock Exchange. European Journal of Economics, Finance and Administrative Sciences, 43(1), 28-34.

Andersson, M., Hedesström, M., \& Gärling, T. (2014). A SocialPsychological Perspective on Herding in Stock Markets. Journal of Behavioral Finance, 15(3), 226-234. https://doi.or $\mathrm{g} / 10.1080 / 15427560.2014 .941062$

Aryeetey, E. (2004). Household asset choice among the rural poor in Ghana. Institute of Statistical, Social and Economic Research, University of Ghana.

Baker, H. K., \& Nofsinger, J. R. (2002). Psychological biases of investors. Financial Services Review, 11(2), 97-116.

Banerjee, A. V. (1992). A simple model of herd behavior. The Quarterly Journal of Economics, 107(3), 797-817.

Bell, D. E. (1982). Regret in decision making under uncertainty. Operations Research, 30(5), 961-981.

Bhandari, G., \& Deaves, R. (2006). The demographics of overconfidence. The Journal of Behavioral Finance, 7(1), $5-11$.

Bikhchandani, S., Hirshleifer, D., \& Welch, I. (1992). A theory of fads, fashion, custom, and cultural change as informational cascades. Journal of Political Economy, 100(5), 992-1026. https://doi.org/10.1086/261849

Bless, H., Clore, G. L., Schwarz, N., Golisano, V., Rabe, C., \& Wölk, M. (1996). Mood and the use of scripts: Does a happy mood really lead to mindlessness?. Journal of Personality and Social Psychology, 71(4), 665-679. https://doi.org/10.1037/00223514.71.4.665

Bower, G. H. (1981). Mood and memory. American Psychologist, 36(2), 129-148. https://doi.org/10.1037/0003-066X.36.2.

Braga, R., \& Fávero, L. P. L. (2017). Disposition Effect and Tolerance to Losses in Stock Investment Decisions: An Experimental Study. Journal of Behavioral Finance, 18(3), 271-280. https://doi.org/10.1080/15427560.2017.13 08946

Brunsson, N. (2014). The Irrational Organization: Irrationality as a Basis for Organizational Action and Change. Management, 17(2), 141-158.

Chen, Y., Weston, J. F., \& Altman, E. (1995). Financial Distress \& Restructuring Models. Financial Management, 24(2), 57-75. https://doi.org/10.2307/3665535

Cheng, P. Y. K. (2014). Decision Utility and Anticipated Discrete Emotions: An Investment Decision Model. Journal of Behavioral Finance, 15(2), 99-108. https://doi.org/10.1080/1 5427560.2014 .908885

Chin, W. (1998). The partial least squares approach to structural equation modeling. Modern Methods for Business Research, 295(2), 295-336. https://doi.org/10.1016/j.aap.2008.12.010

Chorus, C. G. (2014). Risk aversion, regret aversion and travel choice inertia: An experimental study. Transportation Planning and Technology, 37(4), 321-332. https://doi.org/10.1080/0308 1060.2014.899076 
Cianci, A. M. (2008). The Impact of Investor Status on Investors' Evaluation of Negative and Positive, Separate and Combined Information. Journal of Behavioral Finance, 9(3), 117-131. https://doi.org/10.1080/15427560802333589

Cole, S., \& Fernando, N. (2008). Assessing the importance of financial literacy. ADB Finance for the Poor, 9(2), 1-6. https:// doi.org/10.30845/ijhss.v8n8p17

Corzo, T., Prat, M., \& Vaquero, E. (2014). Behavioral Finance in Joseph de la Vega's Confusion de Confusiones. Journal of Behavioral Finance, 15(4), 341-350. https://doi.org/10.1080/ 15427560.2014.968722

Deaves, R., Lei, J., \& Schröder, M. (2019). Forecaster Overconfidence and Market Survey Performance. Journal of Behavioral Finance, 20(2), 173-194. https://doi.org/10.1080/1 5427560.2018 .1505727

Deng, X., Hung, S., \& Qiao, Z. (2018). Mutual fund herding and stock price crashes. Journal of Banking \& Finance, 94(2), 166-184. https://doi.org/10.1016/j.jbankfin.2018.07.014

Dräger, L., Menz, J. O., \& Fritsche, U. (2014). Perceived inflation under loss aversion. Applied Economics, 46(3), 282-293. https://doi.org/10.1080/00036846.2013.844328

Fischhoff, B. (2003). Hindsight $\neq$ foresight: the effect of outcome knowledge on judgment under uncertainty. BMJ Quality \& Safety, 12(4), 304-311. https://doi.org/10.1136/qhc.12.4.304

Fong, W. M. (2013). Risk Preferences, Investor Sentiment and Lottery Stocks: A Stochastic Dominance Approach. Journal of Behavioral Finance, 14(1), 42-52. https://doi.org/10.1080/154 27560.2013.759579

Froot, K. A., Scharfstein, D. S., \& Stein, J. C. (1992). Herd on the street: Informational inefficiencies in a market with short-term speculation. The Journal of Finance, 47(4), 1461-1484. https:// doi.org/10.1111/j.1540-6261.1992.tb04665.x

Gervais, S., \& Odean, T. (2001). Learning to be overconfident. The Review of Financial Studies, 14(1), 1-27.

Gil, E. L. (2015). Leading the Way for Financial Literacy Education: A Case Study on Collaboration. Journal of Business \& Finance Librarianship, 20(1-2), 27-53. https://doi.org/10.1080/089635 68.2015.978710

Guzak, J. R. (2015). Affect in Ethical Decision Making: Mood Matters. Ethics \& Behavior, 25(5), 386-399. https://doi.org/10. 1080/10508422.2014.941980

Haigh, M. S., \& List, J. A. (2005). Do professional traders exhibit myopic loss aversion? An experimental analysis. The Journal of Finance, 60(1), 523-534. https://doi.org/10.1111/j.15406261.2005.00737.x

Hair, J. F., Hult, G. T. M., Ringle, C. M., \& Sarstedt, M. (2017). A Primer on Partial Least Squares Structural Equation Modeling (PLS-SEM) ( $2^{\text {nd }}$ ed.). Thousand Oaks, CA: Sage Publications, Inc.

He, Y., \& Choi, B. R. (2020). China's Outward Foreign Direct Investment Patterns: Evidence from Asian Financial Markets. Journal of Asian Finance, Economics and Business, 7(2), 157168. https://doi.org/10.13106/jafeb.2020.vol7.no2.157
Hilton, D. J. (2001). The Psychology of Financial DecisionMaking: Applications to Trading, Dealing, and Investment Analysis. Journal of Psychology and Financial Markets, 2(1), 37-53. https://doi.org/10.1207/S15327760JPFM0201_4

Hirshleifer, D. (2001). Investor psychology and asset pricing. The Journal of Finance, 56(4), 1533-1597. https://doi. org/10.1111/0022-1082.00379

Hirshleifer, D., \& Hong Teoh, S. (2003). Herd behaviour and cascading in capital markets: A review and synthesis. European Financial Management, 9(1), 25-66. https://doi. org/10.1111/1468-036X.00207

Jurkatis, S., Kremer, S., \& Nautz, D. (2012). Correlated trades and herd behavior in the stock market. SFB 649 Discussion Paper, $1-27$

Kahneman, D., \& Tversky, A. (1979). Prospect theory: An analysis of decisions under risk. Econometrica, 47(2), 263-292. https:// doi.org/10.2307/1914185

Kahneman, D., Knetsch, J. L., \& Thaler, R. H. (1990). Experimental tests of the endowment effect and the Coase theorem. Journal of Political Economy, 98(6), 1325-1348.

Kahneman, D., \& Tversky, A. (2013). Prospect theory: An analysis of decision under risk. In: Handbook of the fundamentals of financial decision making: Part I (pp. 99-127). World Scientific.

Kartini, K., \& Setiawan, D. A. (2017). Factors Influencing Overconfidence Behavior of Stock Investors in Yogyakarta. Jurnal Riset Manajemen Sekolah Tinggi Ilmu Ekonomi Widya Wiwaha Program Magister Manajemen, 4(1), 36-46.

Khanam, Z. (2017). The impact of demographic factors on the decisions of investors during dividend declaration: A study on dhaka stock exchange, bangladesh. IOSR Journal of Business and Management, 19(8), 1-7.

Kim, J. (2004). Impact of a workplace financial education program on financial attitude, financial behavior, financial well-being, and financial knowledge. Proceedings of the Association for Financial Counseling and Planning Education, 22(1), 82-89.

Kiyilar, M., \& Acar, O. (2013). Behavioural finance and the study of the irrational financial choices of credit card users. Annales Universitatis Apulensis Series Oeconomica, 1(11), 46-59

Kliger, D., \& Tsur, I. (2011). Prospect Theory and Risk-Seeking Behavior by Troubled Firms. Journal of Behavioral Finance, 12(1), 29-40. https://doi.org/10.1080/15427560.2011.555028

Lee, J., \& Lee, J. (2015). Analyst Herding Behavior and Analyst Affiliation: Evidence from Business Groups. Journal of Behavioral Finance, 16(4), 373-386. https://doi.org/10.1080/ 15427560.2015.1098640

Loomes, G., \& Sugden, R. (1982). Regret theory: An alternative theory of rational choice under uncertainty. The Economic Journal, 92(368), 805-824. https://doi.org/10.2307/2232669

López-Gutiérrez, C., Sanfilippo-Azofra, S., \& Torre-Olmo, B. (2015). Investment decisions of companies in financial distress. BRQ Business Research Quarterly, 18(3), 174-187. https://doi. org/10.1016/j.brq.2014.09.001 
Lovric, M., Kaymak, U., \& Spronk, J. (2010). Modeling investor sentiment and overconfidence in an agent-based stock market. Human Systems Management, 29(2), 89-101. https://doi. org/10.3233/HSM-2010-0718

Maug, E., \& Naik, N. (1996). Herding and delegated portfolio management. London Business School Quarterly Journal of Finance, 1(2), 265-292. https://doi.org/10.1142/ S2010139211000092

Meier, C., \& De Mello, L. (2019). Investor Overconfidence in Experimental Asset Markets across Market States. Journal of Behavioral Finance, 21(4). 369-384. https://doi.org/10.1080/1 5427560.2019.1692845

Mellers, B. A., Schwartz, A., Ho, K., \& Ritov, I. (1997). Decision affect theory: Emotional reactions to the outcomes of risky options. Psychological Science, 8(6), 423-429. https://doi. org/10.1111/j.1467-9280.1997.tb00455.x

Mellers, B., Schwartz, A., \& Ritov, I. (1999). Emotion-based choice. Journal of Experimental Psychology: General, 128(3), 332-345. https://doi.org/10.1037/0096-3445.128.3.332

Michailova, J., \& Schmidt, U. (2016). Overconfidence and Bubbles in Experimental Asset Markets. Journal of Behavioral Finance, 17(3), 280-292. https://doi.org/10.1080/15427560.2016.12033 25

Mittal, M. (2010). Study of differences in behavioral biases in investment decision-making between the salaried and business class investors. IUP Journal of Behavioral Finance, 7(4), 20.

Morales-Camargo, E., Sade, O., Schnitzlein, C., \& Zender, J. F. (2015). On the Persistence of Overconfidence: Evidence from Multi-Unit Auctions. Journal of Behavioral Finance, 16(1), 68-80. https://doi.org/10.1080/15427560.2015.1000330

Nguyen, D. V., Dang, D. Q., Pham, G. H., \& Do, D. K. (2020). Influence of Overconfidence and Cash Flow on Investment in Vietnam. Journal of Asian Finance, Economics and Business, 7(2), 99-106. https://doi.org/10.13106/jafeb.2020.vo17.no2.99

Nguyen, H. H. (2020). Impact of Foreign Direct Investment and International Trade on Economic Growth: Empirical Study in Vietnam. Journal of Asian Finance, Economics and Business, 7(3), 323-331. https://doi.org/10.13106/jafeb.2020.vol7.no3. 323

Nofsinger, J. R. (2017). The psychology of investing. London, UK: Routledge.

Nofsinger, J. R., \& Sias, R. W. (1999). Herding and feedback trading by institutional and individual investors. The Journal of Finance, 54(6), 2263-2295. https://doi.org/10.1111/00221082.00188

Oehler, A., Wendt, S., Wedlich, F., \& Horn, M. (2018). Investors' Personality Influences Investment Decisions: Experimental Evidence on Extraversion and Neuroticism. Journal of Behavioral Finance, 19(1), 30-48. https://doi.org/10.1080/15 427560.2017.1366495

Peters, E. (2003). Simple and Complex Market Inefficiencies: Integrating Efficient Markets, Behavioral Finance, and Complexity. Journal of Behavioral Finance, 4(4), 225-233. https://doi.org/10.1207/s15427579jpfm0404_5
Pompian, M. M., \& Wood, A. S. (2006). Behavioral finance and wealth management: How to build optimal portfolios for private clients. Hoboken, NJ: John Wiley \& Sons, Inc.

Riff, S., \& Yagil, Y. (2016). Behavioral Factors Affecting the Home Bias Phenomenon: Experimental Tests. Journal of Behavioral Finance, 17(3), 267-279. https://doi.org/10.1080/15427560.20 16.1203324

Rompotis, G. G. (2018). Herding Behavior among ExchangeTraded Funds. Journal of Behavioral Finance, 19(4), 483-497. https://doi.org/10.1080/15427560.2018.1431886

Sahi, S. K., Arora, A. P., \& Dhameja, N. (2013). An Exploratory Inquiry into the Psychological Biases in Financial Investment Behavior. Journal of Behavioral Finance, 14(2), 94-103. https://doi.org/10.1080/15427560.2013.790387

Sarigül, H. (2014). A Survey of Financial Literacy Among University Students. Journal of Accounting \& Finance, 64(2). 207-224

Sarsour, W. M., \& Sabri, S. R. M. (2020). Evaluating the Investment in the Malaysian Construction Sector in the Long-run Using the Modified Internal Rate of Return: A Markov Chain Approach. Journal of Asian Finance, Economics and Business, 7(8), 281287. https://doi.org/10.13106/jafeb.2020.vol7.no8.281

Scharfstein, D. S., \& Stein, J. C. (1990). Herd behavior and investment. American Economic Review, 80(3), 465-479.

Sevdalis, N., \& Harvey, N. (2007). "Investing" versus "Investing for a Reason": Context Effects in Investment Decisions. Journal of Behavioral Finance, 8(3), 172-176. https://doi. org/10.1080/15427560701547487

Shefrin, H. (2007). How the disposition effect and momentum impact investment professionals. Journal of Investment Consulting, 8(2), 68-79.

Statman, M. (2017). Financial Advertising in the Second Generation of Behavioral Finance. Journal of Behavioral Finance, 18(4), 470-477. https://doi.org/10.1080/15427560.2017.1365236

Stotz, O., \& von Nitzsch, R. (2005). The Perception of Control and the Level of Overconfidence: Evidence from Analyst Earnings Estimates and Price Targets. Journal of Behavioral Finance, 6(3), 121-128. https://doi.org/10.1207/ s15427579jpfm0603_2

Thaler, R. (1980). Toward a positive theory of consumer choice. Journal of Economic Behavior \& Organization, 1(1), 39-60. https://doi.org/10.1016/0167-2681(80)90051-7

Thaler, R. H., Tversky, A., Kahneman, D., \& Schwartz, A. (1997). The effect of myopia and loss aversion on risk taking: An experimental test. The Quarterly Journal of Economics, 112(2), 647-661. https://doi.org/10.1162/003355397555226

Venezia, I., Nashikkar, A., \& Shapira, Z. (2011). Firm specific and macro herding by professional and amateur investors and their effects on market volatility. Journal of Banking \& Finance, 35(7), 1599-1609.

Xiao, J. J. (2008). Applying behavior theories to financial behavior. In: Handbook of Consumer Finance Research. https://doi. org/10.1007/978-0-387-75734-6_5 